\title{
LETTER FROM THE PRESIDENT OF THE I.M.A.
}

Dear Members and Colleagues:

Assalam-U-Alaikım

The I.M.A. has been acutely aware of the worsening plight of Foreign Medical Graduates. Being aware of the changing trends in medicine which are occurring in this country, and affecting all of us, the I.M.A. organized a symposium on Foreign Medical Craduates at its 16th Annual Convention, held in Chicago, Illinois, September, 1983, and again at its first Spring Convention, held in Orlando, Florida, March of 1984. The I.M.A. provided a platform at that time for its members to have open discussions with prominent members of organized medicine. Included amongst these were Dr. Frank J. Jirka, Jr., Dr. Samuel Asper, President of the Educationl Council on Foreign Medical Graduates, and representatives of the Federation of State Licensing Boards. These platforms brought to light many grievances of the Foreign Medical Graduate that hitherto had not been brought to the surface. It became evident that the changing trends of medicine today, is not only affecting all the graduates, but is affecting the Foreign Medical Graduate the worst. There are presently three to five thousand Foreign Medical Graduates, fully licensed and capable, who are unable to find appropriate positions for training in this country. Thus they have to serve as cooks, domestics. cab drivers, etc. This no doubt is a degradation of the well qualified immigrant physicians who came to this country with high hopes of bettering their education and skills.

As a result of these discussions certain conclusions were arrived at. Unanimous resolutions were adopted by the gencral body of the I.M.A. at these meetings and were forwarded to the appropriate bodies of organized medicine (JIMA of 1983, Volume 15, Number 4, Page 103).

As a result of these cfforts of the I.M.A. leadership and the effects that these discussions had on the leadership of organized medicine, an Ad-Hoc committee on Foreign Medical Graduates has been recently established by the A.M.A. (American Medical Association), to study the problems facing the Forcign Medical Graduates in the United States. Unfortunately the representatives on the Ad-Hoc Committee have not boen the representatives that were proposed by several of the ethnic organizations. Instead the A.M.A. decided on representatives from those who are already involved in the A.M.A. infra-structure. Thus the question arises whether these representatives will truly represent us or not?

Nonetheless this is a starting point for people in organized medicine to look into the affairs of the Foreign Medical Graduates. This Committee will not be able to solve the problems facing the Foreign Medical Graduates immediately, but at least you have some representatives with whom you can discuss the problems, so they can then discuss them in the Ad-Hoc Committee.

Many of us carne to this country with the dream of achieving a high standard of skill in a specialty of our interest. Some of us have not only achieved this but have left our marks on the milestone of medicine. The majority of us however get so involved in the day to day activities of earning bread and butter for our loved ones that we tend to forget that democratic as this country is, unless we get involved in the process of democracy, we have no voice. Although the A.M.A. has about 300 members in the House of Delegates there are barcly any Foreign Medical Graduates represented. This has left us without any true representation in the only existing organized voice of medicine in this country, that is the A.M.A.

We need to correct this problem immediately. We need to get involved. We need to participate in all ties of organized medicine. Therefore my advice to you is join your hospital executive cornmittees, join your state medical association and national committees. This will be the only way that your voice will ever be heard.

As a Muslim however, our obligations do not end when we stasify our own needs and requirements in this country. We must reach out to help our native country and our brothers. There are a lot of countries that need to make major strides in developing their undergraduate and post-graduate medical education. Many of these developments are related to the economic resources of the particular country. If we can combine all of our resources rather than have each country st riving to develop its own meager resources at its own pace, we could achieve as one body, things of which we can now only dream.

We have enough man power and talents amongst our own which lie untapped at the present tirae. Many of us have the experience, knowledge and willingness to help our fellow brethren that need help. Our petty prejudices have kept us apart. We must think beyond the limits of our communities, nations or cultures, in the interest of the survival of the entire group. It is fundamental that we hold firm and stick to our faith. This, unfortunately, is the quality we all lack.

I call upon all of us to examine our priorities and examine our very souls. If even for a moment we set aside our own selfish needs we will no doubi be able to conquer all of the difficulties that face the Muslim Umma all around the world.

Wassalam.

Peoria, Illinois Dr. M.A.A. Khan

July, 1984 President.

Lslamic Medical

Association of North

America

The Journal of IMA - Vol. 16-January and April 1884-Page 7 